\title{
Introduction: Governance in South, Southeast, and East Asia
}

\author{
Ishtiaq Jamil • Salahuddin M. Aminuzzaman • \\ Sk. Tawfique M. Haque
}

Published online: 3 December 2013

C The Author(s) 2013. This article is published with open access at Springerlink.com

This special issue explores and analyzes governance and policy issues in South, Southeast, and East Asia. ${ }^{1}$ The nine papers in this issue were presented at a similarly titled conference in Dhaka, Bangladesh in 2012. ${ }^{2}$ The authors map governance challenges and analyze its current trends from the perspectives of politics and administration. Public administration and governance systems in these regions have witnessed some phenomenal changes during the last three decades and have played a key role in the economic progress, especially in the Southeast and East Asian nations. Rich with evidence and analyses, these papers use empirical and other research methods to examine contemporary bestpractice paradigms. Their additional aim is to develop the understanding of changes in the forms of governance, both within the national context and in a comparative perspective.

The regions of South, Southeast, and East Asia contain enormous geographical, cultural, religious, and ethnic variation. They are also "diverse in political and constitutional systems and their performance in managing the economy is uneven" (Haque 2001:1290). Some countries in Southeast and East Asia may already qualify as developed nations, but most of South Asia is beset with poor governance, lack of rule of law, and widespread corruption. This is the case despite these countries, in the last decade or so, witnessing steady and impressive economic growth. In the context of governance, the huge differences in the South, Southeast, and East Asian countries reflect the countries' unique cultures, history, demography and geography, political

\footnotetext{
${ }^{1}$ South Asia is represented by Bangladesh, Bhutan, India, Maldives, Nepal, Pakistan, and Sri Lanka. Afghanistan joined in 2005. Our broad definition of Southeast and East Asia includes Burma in the west, China in the north, Japan and the Philippines in the east, and Indonesia in the south.

${ }^{2}$ The papers in this special issue cover only a few countries in South, Southeast, and East Asia. Some are country-specific studies while others are comparative studies.
}

I. Jamil $(\bowtie)$

Department of Administration and Organization Theory, University of Bergen, Bergen, Norway e-mail: ishtiaq.jamil@aorg.uib.no

S. M. Aminuzzaman

Department of Public Administration, University of Dhaka, Dhaka, Bangladesh

S. T. M. Haque

Department of General and Continuing Education, North South University, Dhaka, Bangladesh 
development, and economic growth (Cheung 2011:139). Even within the regions, we observe huge variations of governance and its practice. The papers in this volume cover a number of these issues but do not cover all aspects of governance and all countries in South, Southeast, and East Asia.

The term governance now occupies centre stage and is a buzzword in the social sciences, yet it is being imbued with different meanings and used in different ways (Levi-Faur 2012:3; Pierre and Peters 2000:1). Its usages are ubiquitous with terms such as "good governance", "global governance" (Bevir 2011:1), "sound governance" (Farazmand 2004), and "good enough governance" (Grindle 2007). Its popularity can be chalked up to its inclusiveness: it is broader than the traditional "government" concept, and it includes other actors such as non-governmental organizations and civil society in the process of governance. In the case of South, Southeast, and East Asian states, governance as practiced has been top-down in policy making and implementation. The states in Southeast and East Asia are referred to as developmental states because of the key role the state has played in the social life and economic development in these countries. The financial crisis in 1997 in the region raised doubts about the capacity of the centralized state to sustain the "East Asian miracle", calling for new institutional arrangements (Cheung 2007:257). On the other hand, governance in South Asia has been varied; some countries are managing better than others in terms of steady economic growth, ensuring human security and safety, and political stability. Others are lagging in ensuring and maintaining the basic tenets of democracy, despite the fact that most of these countries have adopted democracy as the form of governance (Jamil et al. 2013). Some South Asian countries are so beset with internal conflicts and confrontations amongst various groups and political parties that they may be termed as 'weak' or even 'failed states'.

Having said this, external and internal pressure and inspiration are spurring reform and institutional reconfiguration within political bodies and governance in South, Southeast, and East Asia. According to Cheung (2011), we increasingly observe reforms that are initiated and inspired by New Public Management (NPM), and good governance is being advocated by international organizations such as the World Bank and the International Monetary Fund. Internal pressures are associated with nation building and a state's capacity-building processes, as well as cultural contexts and political and administrative changes. As a result, we observe various implications of governance in the political, administrative, and economic spheres; these in turn have led to variations in governance practices and institutional arrangements. The reformers' major concerns have been to improve the public sector's efficiency and efficacy, to make it more responsive to citizens' demands and aspirations, to cut public expenditure, and enhance political and administrative accountability (Christensen and Lægreid 2011:1).

In our conceptualization - and also as highlighted in various articles in this issue-governance focuses on the capacity of public institutions (Fukuyama 2013), and participatory democracy (Norris 2012). The capacity of public institutions denotes delivering services and responding to citizens' needs. This may take place both in multi-party democratic countries (such as in Japan) or in authoritarian regimes (many Southeast and East Asian nations, including China and Vietnam). The South Asian states are increasingly failing to deliver in accordance with citizens' preferences; hence citizens are increasingly distrustful of public and political institutions. 
Participatory democracy denotes the inclusion of a wide range of actors in formulating policies. This trend is now unfolding in a number of Southeast and East Asian nations. Participatory democracy is emerging in these states and making them more flexible to reforms. They are allowing hitherto-discouraged actors such as civil society to join in the process of governance, to enter into public-private partnerships and public dialogue. Meanwhile, in the context of South Asian nations, despite an increase of nongovernmental organizations and an active civil society, participation in governance has been limited. Paternalistic politics and patron-clientelism in policies have become widespread, leading to corrupt practices and non-accountable and non-transparent government activities.

Governance as we observe today in South, Southeast, and East Asia has changed considerably over the past few decades, and the future does pose a number of challenges. These developments, present practices, and future challenges are summarized in Table 1.

As is evident from Table 1, future challenges to governance are formidable, especially in the South Asian nations. In spite of becoming wealthier through steady economic growth, these nations are still poorly managed. Their public policy making does not reflect citizens' interests and public officials are not being held accountable for their actions. The major challenge for Southeast and East Asian governance is to open up by allowing other interests to participate in the policy making.

\section{Contents of This Special Issue}

The papers in this volume emphasize that a) governance processes in any country have histories and legacies and are influenced by contextual frameworks; in other words, governance is not necessarily universal, but is significantly affected by the respective country's culture and history. b) There appear to be some paradoxical propositions and trends in the contemporary discourses and empirical observations on governance. c) Governance is the product of its own ecology, and it does tend to maintain a particular pattern. d) Civil society organizations are emerging as strong actors to develop the demand side of governance. d) There are some common challenges in addressing governance issues, especially in terms of policy formulation and implementation. e) Public management reforms can be potential tools for improving governance, and it should be possible for governments to learn from each other's successful endeavours. f) Piecemeal reform measures are more likely to adapt governance initiatives to local needs than are across-the-board reform initiatives. Nine articles appear in this symposium, with the order offered below; they cover a wide range of concepts, ideas, issues, challenges, and opportunities with implications for the wide regions of South, Southeast, and East Asia.

\section{Sound Governance in the Age of Globalization}

The concept of governance has captured an overwhelming amount of academic research and scholarship worldwide for the last twenty years or so, with extensions to virtually every field of study in social sciences and implications for all areas of public, 
Table 1 Nature of governance as practiced in South, South-East, and East Asia

\begin{tabular}{|c|c|c|c|}
\hline \multirow[t]{2}{*}{ Region } & \multicolumn{3}{|c|}{ Nature of governance in South, South-East, \& East Asia } \\
\hline & Historical paths & Contemporary trends & Future challenges \\
\hline $\begin{array}{l}\text { South } \\
\text { Asia }\end{array}$ & $\begin{array}{l}\text { - Break away with } \\
\text { colonialism } \\
\text { - More government and } \\
\text { less governance, i.e., } \\
\text { overextended and } \\
\text { over-centralized state } \\
\text { - Experience with military } \\
\text { and authoritarian } \\
\text { leadership } \\
\text { - Strong bureaucracy based } \\
\text { on strong hierarchy } \\
\text { - Regulated economy }\end{array}$ & $\begin{array}{l}\text { - Widening of scope, allowing } \\
\text { others actors to join the } \\
\text { process of governance } \\
\text { - NPM-inspired reforms } \\
\text { allowing civil society and } \\
\text { private sector engagement } \\
\text { - Globalization and the } \\
\text { primacy of economic } \\
\text { growth } \\
\text { - Policy transfer from } \\
\text { international organizations } \\
\text { in setting the policy agenda } \\
\text { for reforms } \\
\text { - Paternalism in politics, } \\
\text { leading to patron- } \\
\text { clientelistic policy making } \\
\text { - Alliances amongst political } \\
\text { parties is dividing nations, } \\
\text { with the consequence of } \\
\text { infighting amongst various } \\
\text { groups }\end{array}$ & $\begin{array}{l}\text { - Establishing rule of law } \\
\text { - Fostering citizens' trust in } \\
\text { public and political } \\
\text { institutions } \\
\text { - Reinventing government and } \\
\text { bureaucracy as neutral, goal- } \\
\text { and performance-oriented } \\
\text { institutions } \\
\text { - Political and managerial } \\
\text { accountability and } \\
\text { transparency of actions } \\
\text { - Making institutions perform } \\
\text { and deliver } \\
\text { - Governance in terms of equity } \\
\text { and citizenship rights, and } \\
\text { providing human safety and } \\
\text { security } \\
\text { - Solving wicked problems } \\
\text { (reducing corruption, access } \\
\text { to health and education, } \\
\text { making megacities more } \\
\text { liveable, and addressing } \\
\text { environmental hazards) }\end{array}$ \\
\hline $\begin{array}{r}\text { Southeast \& } \\
\text { East Asia }\end{array}$ & $\begin{array}{l}\text { - Break away with socialism } \\
\text { (such as Vietnam, Laos, } \\
\text { Kampuchea, and China) } \\
\text { - Statist approach to rebuild } \\
\text { nations } \\
\text { - The rise of developmental } \\
\text { state } \\
\text { - The domination of } \\
\text { one-party rule } \\
\text { - Dominant authoritarian } \\
\text { leadership }\end{array}$ & $\begin{array}{l}\text { - State directed economy } \\
\text { - Interlocking state-economy- } \\
\text { social systems and elites in } \\
\text { the process of governance } \\
\text { - Increased use of network } \\
\text { governance as a result of the } \\
\text { increase in the number of } \\
\text { semi-government units }\end{array}$ & $\begin{array}{l}\text { - Decentralization and sharing } \\
\text { power with other societal } \\
\text { actors (civil society) in the } \\
\text { governance process, i.e., more } \\
\text { openness and inclusion } \\
\text { - Pragmatic developmentalism in } \\
\text { a globalized world, i.e., } \\
\text { contextualization of global } \\
\text { governance ideas to each } \\
\text { country's needs. } \\
\text { - Piecemeal reform measures } \\
\text { rather than a fast track reform } \\
\text { initiative }\end{array}$ \\
\hline
\end{tabular}

Source: Developed by the authors based on the writings of Cheung $(2007,2011)$

private, and non-profit sector organizations worldwide. Professor Farazmand's comprehensive 'key note' paper, "Sound Governance in the Age of Globalization," presented at the Conference addresses this and many other issues, and sets a theoretical and practical tone for discussions by participants and a starting point for this special symposium issue. He raises eye opening questions as to "why governance now and not before the stampede of globalization" with issues and propositions. He prefers application of "sound governance" over 'good governance', and 'bad, and ugly governance' as prescribed by globally dominant institutions like the World Bank, International Monetary Fund, USAID, and others. What is good for global institutions or advanced industrialized countries may be bad or ugly for developing or less developed nations, he argues. 


\section{History and Context Matter}

Although discourse and discussion on governance have entered the limelight in the 1990s, they have a long history. Ancient and medieval political philosophy developed various perspectives on the better forms and functions of government in relation to given contexts. Tawfique Haque could be said to continue this tradition by analysing the concepts of power and authority from South Asian perspectives. He explores the South Asian forms of governance on the basis of Hindu and Muslim political thought and makes a comparison between these two religious thought forms. He analyzes how the relationships between the ruler and the ruled are conceptualized.

\section{The Paradox of Good Governance}

Popular trust - usually understood as an indicator of governance quality — is quite high for major institutions like parliament and the central government bureaucracy in Bangladesh. This is a finding of Steinar Askvik and Ishtiaq Jamil. However, according to a number of expert evaluations, governance in Bangladesh is quite poor, so public and political institutions in Bangladesh do not actually stand out as very trustworthy. The high level of popular institutional trust presents a paradox since it is misplaced. It implies some kind of blind or naive trust, which may be dysfunctional for the emergence of a democratic governance system.

\section{The Ecology of Governance}

Salahuddin Aminuzzaman discusses the question of how Bangladesh could achieve impressive and steady economic growth despite its current struggle with corrupt practices such as poor governance and widespread patron-clientelism. This puzzle can be understood if we observe the policy making process, especially the policy formulation stage and how it is influenced by external demands, globalization measures, and internal commitment from the highest political leadership. Similarly, Shamsul Haque argues that behind NPM and post-NPM led reforms in Southeast Asian countries, there are external factors such as globalization that may have led to the shaping of the neo-liberal reconfiguration of the state and the market-driven reinvention of state policies. Haque explains how the linkages between the globalization process, state formation and transformation, and public sector reinvention have led these states to embrace neoliberal reforms.

\section{CSO as Partners of Governance}

Civil Society Organizations (CSOs) are emerging as strong actors on the demand side of governance. CSOs have the potential to positively collaborate with governments. They seem to have their own cultural characteristics, so the degree and nature of collaboration with governments would vary at the level of economic and social development and in light of the political milieu. Concentrating on four large cities in South, Southeast, and East Asia (Tokyo, Seoul, Manila, and Dhaka), Yutaka Tsujinaka, Shakil Ahmed and Yohei Kobashi analyze how CSOs collaborate with governments through institutional 
mechanisms. Based on a large longitudinal data set, this researcher team argues that institutional arrangements have a positive impact on collaboration in developed countries. CSOs in Tokyo have better combined collaborative and institutional processes than those in the other three cities. Governance in Seoul is more polarized than in the other cities, and in both Manila and Dhaka, CSOs have a high degree of institutionalized relations with the government, but still do not collaborate much with it.

\section{The Challenges of Policy Formulation and Implementation}

Even when a government sets up constitutional guarantees and a policy framework, if compliance with policy implementation processes is low and insignificant, this will result in discrimination, poor governance, and non-responsiveness on the part of the government. Lasna Kabir presents just such a scenario based on a study conducted in Bangladesh, India, and Pakistan. The study pursues the question of why so few women are found in the higher echelon of bureaucracy, despite the constitutional guarantee of equal rights and opportunities. Among other factors, the dominant socio-political culture imposes a permeable glass ceiling that blocks true gender representation in the public administration systems of these countries.

\section{Policy Learning and Design}

Of course governance is conceptualized and practiced differently in different contexts. Nevertheless, despite the variance of conceptions, the basic tenets of good governance practices have been poorly implemented in many developing countries, and their outcomes have not been very successful. This may be due to overambitious demands of governance - demands which make it difficult to operationalize governance and its use. In this regard, Ahmed Shafiqul Haque argues that many of the desired values of governance can be attained through the effective design and implementation of public management reforms. The case of Hong Kong demonstrates that public management reforms can be potential tools for updating and adjusting the structures and practices in developing countries. They can, he argues, help ensure the benefits of the desired values of governance, yet without taking the enormous risks that are involved in making and implementing decisions based on entirely political considerations.

Open Access This article is distributed under the terms of the Creative Commons Attribution License which permits any use, distribution, and reproduction in any medium, provided the original author(s) and the source are credited.

\section{References}

Bevir, M. (2011). Governance as theory, practice and dilemma. In M. Bevir (Ed.), The Sage handbook of governance. London: Sage.

Cheung, A. B. I. (2011). NPM in Asian countries. In T. Christensen \& P. Lægreid (Eds.), The Ashgate Research Companion to new public management (pp. 131-144). Farnham: Ashgate.

Cheung, A. B. I. (2007). The politics of administrative reforms in Asia: paradigms and legacies, paths and diversities. Governance: An International Journal of Policy, Administration, and Institutions, 18(2), 257-282. 
Christensen, T., \& Lægreid, P. (2011). Introduction. In T. Christensen \& P. Lægreid (Eds.), The Ashgate Research Companion to new public management (pp. 1-13). Farnham: Ashgate.

Haque, S. (2001). Governance and public management: the South Asian context. International Journal of Public Administration, 24(12), 1289-1297.

Farazmand, A. (Ed.). (2004). Sound governance: Policy and administrative innovations. Westport: Praeger Publishers.

Fukuyama, F. (2013). What is governance? In Governance: An International Journal of Policy, Administration, and Institutions, Wiley Periodicals, Inc. doi:10.1111/gove.12035.

Grindle, M. (2007). Good enough governance revisited. Development Policy Review, 25(5), 553-574.

Jamil, I., Askvik, S., \& Dhakal, T. N. (2013). Understanding governance in South Asia. New York: Springer. doi:10.1007/978-1-4614-7372-5 2.

Levi-Faur, D. (2012). From "big government" to "big governance"? In D. Levi-Faur (Ed.), The Oxford handbook of governance (pp. 3-18). Oxford: Oxford University Press.

Norris, P. (2012). Making democratic governance work: How regimes shape prosperity, welfare, and peace. Cambridge: Cambridge University Press.

Pierre, J., \& Peters, B. G. (2000). Governance, politics and the state. London: MacMillan Press Ltd.

Ishtiaq Jamil is associate professor, Department of Administration and Organization Theory, University of Bergen, Norway.

Salahuddin Aminuzzaman, professor, Department of Public Administration, University of Dhaka, Bangladesh.

Sk. Tawfique, associate professor, Department of General and Continuing Education, North South University, Bangladesh. 